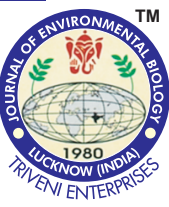

\title{
A comparative study on the effect of dispersed and undispersed Kuwait crude oil on egg hatching and larval survival of Epinephelus coioides
}

Paper received: 13.01 .2018

Revised received: 19.07.2018

Re-revised received: 15.09.2018

Accepted: 29.09.2018

\begin{abstract}
Authors Info
Q. Karam ${ }^{1 *}$, M. Ali',

M.N.V. Subrahmanyam ${ }^{1,4}$, K. Al-Abdul Elah $^{1}$, M. Bentley ${ }^{2.3}$ and M.U. Beg ${ }^{1}$

'Environment \& Life Sciences Research Center, Kuwait Institute for Scientific Research, Safat-13109, Kuwait

${ }^{2}$ Dove Marine Laboratory, School of Marine Science and Technology, Newcastle University, Newcastle upon Tyne, NE1 7RU, United Kingdom

${ }^{3}$ Newcastle University, Singapore, 567 739, Singapore

${ }^{4}$ Regional Organization for the Protection of the Marine Environment (ROPME), Safat 13124, Kuwait

*Corresponding Author Email : qusaie.karam@gmail.com
\end{abstract}

\section{Edited by \\ Dr. Sumati Gaumat}

Reviewed by Dr. Abhed Pandey Dr. Penelope J. Watt

\section{Abstract}

Aim : The objective of the present study was to investigate the effects of dispersed and undispersed Kuwait crude oil on egg hatching and larval survival of Epinephelus coioides.

Methodology : In the present study, the toxic effects of crude and dispersed oil using three formulations of oil dispersants against multiple life stages of Epinephelus coioides was assessed. The lethal concentration was calculated by ToxCal囚 software developed by Tidepool Scientific, LLC.

Results : Specifically, the following life stages were investigated: embryonated eggs (EE), larvae hatched during exposure (LHE) and hatched larvae (HL). Chemical analysis showed that Total Petroleum Hydrocarbon (TPH) concentrations were higher in dispersed than undispersed oil solutions, indicating accommodation of more petroleum hydrocarbons in the aqueous phase. Acute static toxicity tests produced variable $\mathrm{LC}_{50}$ values for all chemical preparations and all fish life stages. Crude oil dispersed with both Corexit ${ }^{\circ}$ EC 9500A and Corexit $\Omega$ EC 9527A separately was more toxic to both EE and LHE stages than undispersed oil, but crude oil dispersed with Slickgone® NS resulted in lower toxicity. Furthermore, all three types of dispersed oil exerted higher toxicity than undispersed oil at $\mathrm{HL}$ stage.

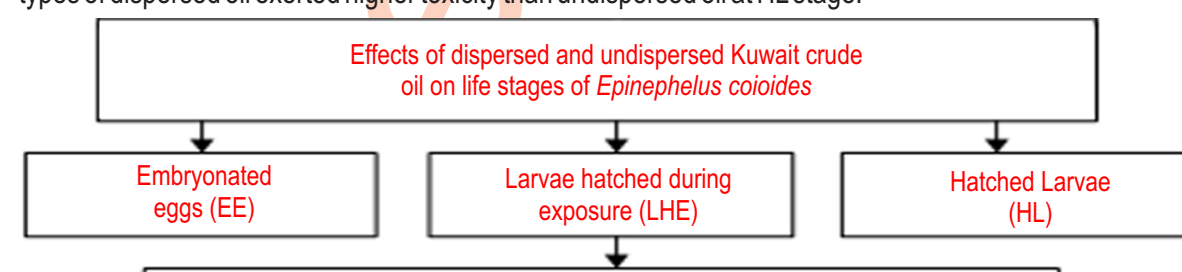

Total petroleum hydrocarbons were higher in dispersed than in undispersed oil

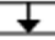

Kuwait crude oil dispersed with both Corexit ${ }^{\circledR}$ EC 9500A and Corexit ${ }^{\circledR}$ EC 9527A separately was more toxic to both EE and LHE stages than undispersed oil

Kuwait crude oil dispersed with Slickgone ${ }^{\circledR}$ NS resulted in lower toxicity. For HL stages, all three types of dispersed oil exerted higher toxicity than undispersed oil

Interpretation : A life stage dependent effect demonstrated variation in the toxicity of both dispersed and undispersed crude oil to fish. Few life stages were more sensitive than others to either dispersed or undispersed crude oil toxicity. While dispersion of an oil slick with oil dispersant has proved to be an effective tool in the oil response strategy, the fate of dispersed oil can exert lethal effects on embryo-larval stages of marine fish present near the spill.

Key words: Embryo-larval stages, Epinephelus coioides, Kuwait crude oil, Total petroleum hydrocarbons

How to cite : Karam, Q., M. Ali, M.N.V. Subrahmanyam, K. Al-Abdul Elah, M. Bentley and M.U. Beg:A comparative study on the effect of dispersed and undispersed Kuwait crude oil on egg hatching and larval survival of Epinephelus coioides. J. Environ. Biol., 40, 192-199 (2019). 


\section{Introduction}

Oil spills affect aquatic life and their habitats in many ways (Birtwell et al., 1999). The severity of the impact depends on the type and amount of oil spilled, season and weather, type of shoreline, and type of wave and tidal energy in the spill area (Martınez-Gomez et al., 2010). Chemical substances and other related petroleum products are transported across global regions by ships or pipelines creating a possibility of spillage with the potential risk of environmental pollution (Daling et al., 1990). In 1991, the Arabian Gulf experienced an oil spill accident which was estimated to be around 816,000 metric tonnes (Pearce, 1993; SOAFD, 1993; Wolf et al., 1993).

Kuwait is one of the major oil-producing countries in the Arabian Gulf, and marine pollution is one of the most significant environmental issues with oil input from waste discharged is estimated to be 26,905 tonnes per year (UNEP, 1999). Spilled oil causes developmental abnormalities and mortality in zooplankton and early-life stages of other marine organisms (Afolabi et al., 1985; NRC, 1985; Powell et al., 1985; Otitoloju and Adeoye, 2003; Karam et al., 2014). The toxicity of crude oil is, therefore, collectively due to the toxicity of organic and inorganic chemicals present, and its toxicity is further interpreted as the fraction of crude oil which can induce deleterious effects on marine fish species.

Oil dispersants are used for rapid removal of spilled oil from the sea surface and then dissolving oil into the water column. This can be performed by reducing the interfacial tension between oil and water and assist in the formation of minute droplets or mixed oil surfactant micelles which disperse in the water column where they can be diluted and biodegraded (ROPME, 1998). Dispersants are defined as chemical formulations that consist of individual components called surfactants, which possess two distinct oleophilic (oil-liking) and hydrophilic (water-liking) groups. Furthermore, the size of small oil droplets decreases due to dispersant, leading to an increase in the surface area exposed to water. These oil droplets determine oil toxicity (Ramachandran et al., 2004; Brannon et al., 2006), a result, the concentration of oil in the water column increases, thereby increasing the concentration of dissolved polycyclic aromatic hydrocarbons, which might result in fish toxicity (Canevari, 1978; ROPME, 1998; Couillard et al., 2005). Although utilization of oil dispersants is an effective mean to combat oil spills in marine waters, there still exist numerous concerns about the toxic effect of dispersed oil on marine fish (Otitoloju, 2005; Venosa and Holder, 2007; Nyman etal., 2007).

Many questions still remain unanswered about indirect toxicological effects of acute exposure to oil pollution and PAHs on the health of aquatic organisms (Bonsdorff et al., 1990; Bejarano et al., 2006). Orange-spotted grouper (Epinephelus coioides), locally named hamoor, is a key species in the aquatic ecosystem and an ideal model for toxicological study (Hussain et al., 1981). It is one of the most highly priced seafood, and the demand of global markets demand exceed their supply, making orange-spotted grouper an economically important fish species around the world. In view of the above, this study mainly focused on the sensitivity of two different exposure regimes and to detect the dispersed and undispersed crude oil levels among the embryonated eggs and larval stages of Epinephelus coioides.

\section{Materials and Methods}

Epinephelus coioides was selected as a test species based on the criteria of ADEC (2000). The epinepheline serranids, form an important taxonomic group both from an ecological and commercial perspective (Sluka et al., 2001; Sadovy de Mitcheson et al., 2013). E. coioides is common in the Arabian Gulf where it is the most important commercially exploited species (Randall, 1995). This fish also forms an important component in the marine food web as their larvae feed on copepods and, along with other larval fish, are being preyed upon by chaetognaths and adult fish such as silver pomfrets (Pampus argenteus) (Baier and Purcell, 1997; Abdurahiman et al., 2006; 2010). Different life stages, embryonated eggs, larvae hatched during exposure, and hatched larvae of $E$. coioides were obtained from the hatchery of the Aquaculture Program at Kuwait Institute for Scientific Research (KISR). The spawning period of this fish is from March to June; and this fish has been successfully cultured and extensively studied in Kuwait Institute for Scientific Research (KISR). The physico-chemical parameters of the water used in this study is as follows: dissolved oxygen: 5-6 mg..$^{-1}$, temperature: $20-28^{\circ} \mathrm{C}$, salinity: $40-42 \mathrm{ppt}$ and $\mathrm{pH}$ 8.2-8.6.

Kuwait Export Crude Oil (KCO) (API-3.18) was procured from the Petroleum Research Center (PRC) of KISR and stored at room temperature $\left(26^{\circ} \mathrm{C}\right)$ in dark. Kuwait Crude Oil technical specifications are as follows: gravity: 30.18 SG, density: $0.8744 \mathrm{~g}$ $\mathrm{ml}^{-1}$ at $15^{\circ} \mathrm{C}$, sulphur content: $2.6 \%$ weight, viscosity: $17.38^{\circ} \mathrm{C}$ at $20^{\circ} \mathrm{C}$ and Conradson Carbon Residue: CCR $6.2 \%$ weight. Chemical dispersants, Corexit@ EC 9500A, Corexit@ EC 9527A, and Slickgone ${ }^{\circledR}$ NS were procured from their original manufacturers Onedo Nalco Ltd. (2005), United Kingdom local agent Bobyan Shipping and Marine Services, and Dasic United Kingdom (2007) (local agent Middle East Chemical Manufacturing $\mathrm{Co}_{\text {.). }}$.

Natural seawater was obtained from the near-shore wells and was filtered through a $0.45 \mu \mathrm{m}$ Whatman $\circledast$ sterile membrane filter before being used for preparing water-accommodated fraction (WAF) and dilutions. One gram KCO filtered seawater used for preparing WAF, and $0.1 \mathrm{~g}$ oil dispersant was selected and layered over the oil slick in a 2I glass aspirator bottle, for preparing chemically-enhanced water-accommodated fraction (CE-WAF). Crude oil and dispersants were layered over a known volume of filtered seawater, mixed for $24 \mathrm{hrs}$, and then left to stand for complete phase (oil/water) separation. WAF and CE-WAF solutions were drained, collected in amber bottles and preserved in a refrigerator until further use. A $96 \mathrm{hr}$ acute toxicity tests were conducted following OECD Guidelines for the Testing of 
Chemicals-Fish Embryo Toxicity (FET) Test (OCED, 2006). Solutions prepared from the following exposure chemicals were used: KCO alone (KCO WAF); KCO + Corexist $(9500$ dispersant (Corexist $₫ 9500$ CE-WAF); KCO + Corexist $₫ 9527$ (Corexist $₫ 9527$ CE-WAF and KCO + Slickgone $®$ dispersant (Slickgone ${ }^{\circledR}$ CE-WAF). Five serial dilutions of $100 \%, 50 \%$, $25 \%, 12.5 \%$ and $6.25 \%$ were used to estimate the $\mathrm{LC}_{50}$ concentrations and $95 \%$ confidence intervals (Environment Canada, 1990). KCO WAF and KCO plus three individual oil dispersant (KCO CE-WAF) dilutions were made in $100 \mathrm{ml}$ glass beakers and made up to a final volume of $50 \mathrm{ml}$ of exposure medium (WAF or CE-WAF). Serial dilutions were made in multiple replicates with non-toxic controls (only filtered seawater) for each replicate.

The acute static toxicity (non-renewal) test was conducted using the following fish developmental stages: embryonated fish eggs (EE) brought from the hatchery after 24 $\mathrm{hr}$ of their release; larvae hatched during exposure (LHE) from the same embryonated eggs exposed in the same test regime so that embryos and larvae of the same embryos were exposed for a total of $96 \mathrm{hr}$, and already post hatched larvae $(\mathrm{HL})$ which were exposed for $96 \mathrm{hr}$ to the test chemicals. Endpoints for the toxicity tests were: successful egg hatching at $48 \mathrm{hr}$, and mortality of either LHE or HL stages at $96 \mathrm{hr}$. Eggs of dead fish were counted at 24 or $48 \mathrm{hr}$, and dead fish larvae were counted at $24,48,72$ and $96 \mathrm{hr}$, respectively.

Toxicity tests were terminated after $96 \mathrm{hr}$ of exposure. Fish larvae were not fed throughout the exposure period. No feeding was required as the yolk sac nourishes fish larvae for three days and the oil globule further nourishes the same larvae for additional two days. EE were washed and checked for complete fertilization, and toxicity tests were carried out $8 \mathrm{hr}$ postfertilization. For $\mathrm{HL}$, toxicity tests were initiated $24 \mathrm{hr}$ posthatching. Normally, the mass of an egg and larvae is about 0.75 and $0.10 \mathrm{mg}$, respectively. A minimum of 10 to 30 fish larva (EE or $\mathrm{HL}$ depending on availability) were placed in $100 \mathrm{ml}$ glass beakers using a glass wide mouth Pasture pipette.

Analysis of total petroleum hydrocarbons was carried out by extracting $100 \mathrm{ml}$ of WAF. CE-WAF solutions were extracted by adding MERCK@ dichloromethane $\left(\mathrm{CH}_{2} \mathrm{Cl}_{2}\right)$. The mixture was centrifuged, dried over MERCK $®$ grade anhydrous sodium sulfate $\left(\mathrm{Na}_{2} \mathrm{SO}_{4}\right)$ and glass wool, which were pre-soaked and then the solvent layer was withdrawn and collected. The collected extract was then analyzed by using an RF-5301 PC SHIMADZU $®$ spectrofluorophotometer using $310 \mathrm{~nm}$ excitation and $360 \mathrm{~nm}$ emission wavelengths. The levels of TPH were calculated against a prepared standard multipoint calibration curve and reported regarding the Kuwait crude oil equivalents (MOOPAM, 1999).

Statistical analysis: Minitab® Statistical Software-Version 17@ 2016, Minitab Inc. was used for conducting statistical analysis. A general linear model (GLM) was used to determine if the exposure concentration (\%) and exposure time (hr) exerted a significant effect on fish egg hatching and larval survival during toxicity tests. The GLM functions on the premise and predicts one variable (dependent), In this study, it is the hatching or larval survival success response, from one or more variables (independent) like exposure concentration (\%) and exposure time (hr). Lethal concentration, which affects $50 \%$ of the exposed fish population $\left(\mathrm{LC}_{50}\right)$, and the no-observed-effect concentration (NOEC) were calculated by ToxCal@ software developed by Tidepool Scientific, LLC.

\section{Results and Discussion}

Chemical characterization of WAF demonstrated that as oil loadings increased, TPH in WAF solutions changed slightly and were not proportional to the increase in oil loadings, indicating that saturation of water-soluble compounds was achieved at $1 \mathrm{~g}$ oil l' seawater loading (TPH= $2.2 \mathrm{mg}^{-1} \mathrm{I}^{-1}$ ), and a further increase in oil content could not substantially increase partitioning of watersoluble compounds in the aqueous medium (Fig. 1.). Dispersion of crude oil with three oil dispersants separately resulted in variable TPH concentrations that reflected the ability of individual dispersant to solubilize some petroleum hydrocarbons in WAF more than other. Chemical analysis revealed that Corexit $₫ 9500$ CE-WAF had the highest TPH concentration (33.2 $\mathrm{mg} \mathrm{l}^{-1}$ ), followed by Corexit $($ ) 9527 CE-WAF (17.7 $\left.\mathrm{mg} \mathrm{l}^{-1}\right)$, Slickgone® NS CE-WAF (5.1 $\left.\mathrm{mg} \mathrm{l}^{-1}\right)$ and $\operatorname{KCO} \operatorname{WAF}\left(2.0 \mathrm{mgl}^{-1}\right)$ (Fig. 1.), respectively

Eggs of $E$. coioides exposed to $1 \mathrm{~g} \mathrm{oil}^{-1}$ seawater $\mathrm{KCO}$ WAF showed more than $90 \%$ hatching in most of the exposure concentrations after $24 \mathrm{hr}$ exposure, and the same situation was observed with eggs in the control tanks during the same period of time. Hatching percentages were increased to $100 \%$ at $48 \mathrm{hr}$ in most of the test concentrations, except at highest concentration where it decreased to $87 \%$. Eggs that did not hatch at either 24 or $48 \mathrm{hr}$ were considered dead. The mean $48 \mathrm{hr} \mathrm{LC}_{50} \mathrm{~g}$ oil l-1 seawater \pm SD calculated from three replicates was $>1.0 \pm 0.0 / 0.0$ with a $95 \%$ confidence interval of 0.933-1.072. The effect of exposure time and concentration on egg hatching was not statistically significant $(p>0.05)$, and only exposure concentration had a statistically significant effect $(p<0.05)$. The NOEC was $<1 \mathrm{~g} \mathrm{KCO} \mathrm{I}^{-1}$. E. coioides larvae $(\mathrm{HL})$ showed $100 \%$ larval survival until $96 \mathrm{hr}$ of exposure in controls, and at 3.12, 6.25 and $12.5 \%$ WAF/KCO dilutions. The survival of larvae was reduced by $2 \%$ and $53 \%$ at $25,50 \%$ KCO WAF dilutions, respectively.

At the highest concentration, $13 \%$ of the eggs were unhatched, the larvae that hatched did not survive, and all of them died by $96 \mathrm{hr}$ of exposure. The average $\mathrm{LC}_{50}$ calculated for the three replicates of LHE at $24 \mathrm{hr}$ was $1.035 \pm 0.06 / 0.035,48 \mathrm{hr} L C 50$ $1.0 \pm 0.0 / 0.0,72 \mathrm{hr} \quad \mathrm{LC}_{50} \quad 0.92 \pm 0.21 / 0.12$, and $96 \mathrm{hr} \quad \mathrm{LC}_{50}$ $0.46 \pm 0.1 / 0.06$ with a $95 \%$ confidence interval of $0.321-0.752$ for $96 \mathrm{hr} \mathrm{LC}_{50}$ (Table 1). The effect of exposure time and concentration on LHE was statistically significant $(p<0.05)$. The NOEC was $0.25 \mathrm{gCO}^{-1}$. E. coioides larvae $(\mathrm{HL})$ were exposed to serially diluted KCO WAF $1.0 \mathrm{~g} \mathrm{KCO} \mathrm{I}^{-1}$ seawater. In control, survival 
Table 1: General Linear Model test showing the effect of oil and dispersed oil on variable life stages of $E$. coioides which was significant $(p<0.05)$ and as determined by the lethal concentrations which affects $50 \%$ of exposed larvae $\left(\mathrm{LC}_{50}\right)\left(\mathrm{gl}^{-1}\right)$ for Water-accommodated fraction (WAF) and chemicallyenhanced water-accommodated fraction (CE-WAF's) of Kuwait crude oil (KCO) showing dispersed oil as being more toxic than KCO WAF for all life stages

\begin{tabular}{|c|c|c|c|c|c|}
\hline Life stages & $\begin{array}{l}\text { KCO WAFI } \\
\text { SD/CI }\end{array}$ & $\begin{array}{l}\text { Corexit } \circledast 9500 \\
\text { CE-WAF/SD/Cl }\end{array}$ & $\begin{array}{l}\text { Corexit } ₫ 9527 \text { CE- } \\
\text { WAF/SD } \pm / \text { Cl }\end{array}$ & $\begin{array}{l}\text { Slickgone® NS CE- } \\
\text { WAF/ SD/Cl }\end{array}$ & $p$ \\
\hline \multirow[t]{2}{*}{$\mathrm{EE}\left(48 \mathrm{hr} \mathrm{LC}_{50}\right)$} & $>1.0 \pm 0.0 /$ & $0.53 \pm 0.13 /$ & $0.17 \pm 0.055 /$ & $2.34 \pm 1.69 /$ & $p<0.05$ \\
\hline & 0.933-1.072 & $0.356-1.49$ & $0.128-0.229$ & $0.453-2.147$ & \\
\hline \multirow[t]{2}{*}{ LHE(96 hr LC $\left.{ }_{50}\right)$} & $0.46 \pm 0.1 /$ & $0.21 \pm 0.12 /$ & $0.08 \pm 0.020 /$ & $1.18 \pm 0.919 /$ & $p<0.05$ \\
\hline & $0.321-0.752$ & $0.15-0.3$ & $0.063-0.121$ & $0.524-3.236$ & \\
\hline \multirow[t]{2}{*}{ *HL(96 hr LC $\left.{ }_{50}\right)$} & $0.93 \pm 0.77 /$ & $0.015 / 0.0$ & $0.01 / 0.08$ & $0.045 / 0.040$ & $p<0.05$ \\
\hline & $0.465-0.917$ & $13-0.018$ & $9-0.0113$ & $9-0.0498$ & \\
\hline
\end{tabular}

$\mathrm{EE}=$ Embryonated Egg; LHE= Larvae Hatched during Exposure; $\mathrm{HL}=$ Hatched Larvae; $\mathrm{LC}_{50}=$ :Lethal Concentration affecting $50 \%$ of exposed fish; population; $\mathrm{SD} \pm=$ Standard Deviation; $\mathrm{Cl}=95 \%$ Confidence Interval and $*=$ no $\mathrm{SD}$ only $\mathrm{LC}_{50}$ and $\mathrm{Cl}$

success was $97 \%$ during $24 \mathrm{hr}$ exposure period, which decreased to $96 \%$ at $96 \mathrm{hr}$. The $100 \%$ concentration of KCO WAF exerted some toxic effects as the survival percentage was reduced from $100 \%$ at $24 \mathrm{hr}$ exposure period to $21 \%$ at $96 \mathrm{hr}$. At lower dilutions, the minimal effect was observed as survival ranged from 87 to $99 \%$ until $96 \mathrm{hr}$ exposure period. The average $\left(\mathrm{LC}_{50} \mathrm{~g}_{\text {oil }}{ }^{-1}\right.$ seawater \pm $\mathrm{SD})$ calculated from nine replicates after $24 \mathrm{hr}$ was $1.26 \mathrm{~g} \mathrm{KCO} \mathrm{I}^{-1}$ seawater for $\mathrm{HL}$. This was comparably toxic to both 24 and $48 \mathrm{hr}$ $\mathrm{LC}_{50}$ for the EE stages which were 1.075 and $>1.0 \mathrm{~g} \mathrm{KCO} \mathrm{I}^{-1}$ seawater, respectively. Conversely, the average $L_{50}$ values of nine replicates for $\mathrm{HL}$ larvae at $24 \mathrm{hr}$ were $1.26 \pm 0.56 / 0.19,48 \mathrm{hr}$ $\mathrm{LC}_{50} 1.25 \pm 0.3 / 0.10,72 \mathrm{hr} \mathrm{LC}{ }_{50} 1.47 \pm 1.55 / 0.52$, and $96 \mathrm{hr} \mathrm{LC}$ $0.93 \pm 0.77 / 0.25$ seawater, with $(0.465-0.917) 95 \%$ confidence intervals for $96 \mathrm{hr}$. The results demonstrated that $\mathrm{HL}$ showed more resistance (less toxicity) to KCO WAF than LHE during KCO WAF exposure ( $96 \mathrm{hr} \mathrm{LC}_{50} 0.468 \mathrm{~g} \mathrm{KO} \mathrm{I}^{-1}$ seawater). The effect of exposure time and concentration of $1 \mathrm{~g} \mathrm{KCO}^{-1}$ seawater on survival success of larvae was statistically significant $(p<0.05)$. The NOEC was $<0.25 \mathrm{~g} \mathrm{KCO}^{-1}$ (Fig. 2). It appeared that $1 \mathrm{~g} \mathrm{KCO}^{-1}$ seawater loading could be more readily partitioned in seawater than $20 \mathrm{~g} \mathrm{KCO} \mathrm{I}^{-1}$ seawater loading during KCO WAF preparation, which contributed more to its toxicity against $E$. coioides larvae.

The present study, to our knowledge, is the first report on the subsequent fate of early life stages of $E$. coioides exposed to crude oil and dispersed oil. Fish toxicity data are highly variable due to several factors such as maturity, species and size that govern the overall sensitivity of a test system. Different fish species and life stages have variable responses to the toxic effect of dispersed and un-dispersed crude oils (NRC, 2003). Early life stages of fish tend to be most sensitive to crude oil exposure, and comparison of toxicity results among test species and their life stages, and the types of toxicants investigated are complex, if not impossible,because there are significant differences in methodologies used to generate valid data (Shales, 1989; Norcross et al., 1997; Singer et al., 2000). The life stages of $E$. coioides responded differently to KCO WAF, and it was found to be more toxic to larvae hatched during exposure, than hatched larvae, or embryonated egg stage which was the most resistant stage to toxic effect. In several studies, a discrepancy in sensitivity to hydrocarbons between developmental stages has been observed; a fish larvae and young fry are more sensitive to water-soluble fractions than eggs (Kunhold, 1970; Struhsaker et al., 1974; Moles et al., 1979).

In contrast to the present findings, Raimondo et al. (2014) observed developmental defects and cardiotoxicity in zebrafish (Danio rerio) embryos exposed to sediments contaminated with South Louisiana crude oil. Barron et al. (2004) indicated that the toxicity of WAF and CE-WAF solutions were similar in exposed fish eggs and larvae,while other studies have demonstrated mixed responses and a decreased toxicity of CE-WAF solution in comparison to WAF (Pollino and Holdaway, 2003; Gagnon and Holdaway, 2000; Wheelock et al., 2002; Georgiades et al., 2003). In contrast to our study, Carls et al. (1999) observed that exposure of herring fish to oil increased in polycyclic aromatic hydrocarbons concentration in the fertilized eggs, but no considerable negative effects were noticed at the early stages of life.

The effect of CE-WAF mixtures on fish species examined was variable, resulting in a species and life stage dependent effect. Also, when living organisms are simultaneously, exposed to two or more chemicals the specific interaction between the constituents may result in an enhanced ultimate effect of the toxic chemicals (Cluevers, 2003; Otitolujo, 2003; 2005; Samuel et al., 2008). Exposure analysis of Kuwait crude oil wateraccommodated fraction (KCO WAF) revealed that (Table 1) the $48 \mathrm{hrLC}_{50}$ for embryonated egg stage was $>1.0 \pm 0.0 \mathrm{gl}^{-1}$, for larvae hatched during exposure the $96 \mathrm{hr} \mathrm{LC}_{50}$ was $0.46 \mathrm{~g} \mathrm{l}^{-1} \mathrm{C}$, and for hatched larvae the $96 \mathrm{hr} \mathrm{LC}_{50}$ was $0.93 \mathrm{~g} \mathrm{l}^{-1}$. For chemicallyenhanced water-accommodated fraction of Kuwait crude oil (KCO CE-WAF), EE $48 \mathrm{hr} \mathrm{LC}_{50}$ for Corexit ${ }^{\circ} 9500$ CE-WAF was $0.53 \mathrm{gl}^{-1}$, for LHE the $96 \mathrm{hr} \mathrm{LC}_{50}$ was $0.21 \mathrm{gl}^{-1}$, and for $\mathrm{HL}$ the $96 \mathrm{hr}$ $\mathrm{LC}_{50}$ was $0.015 \mathrm{~g} \mathrm{I}^{-1}$. For Corexit $₫ 9527 \mathrm{CE}-W A F$, the $48 \mathrm{hr} \mathrm{LC}_{50}$ for 


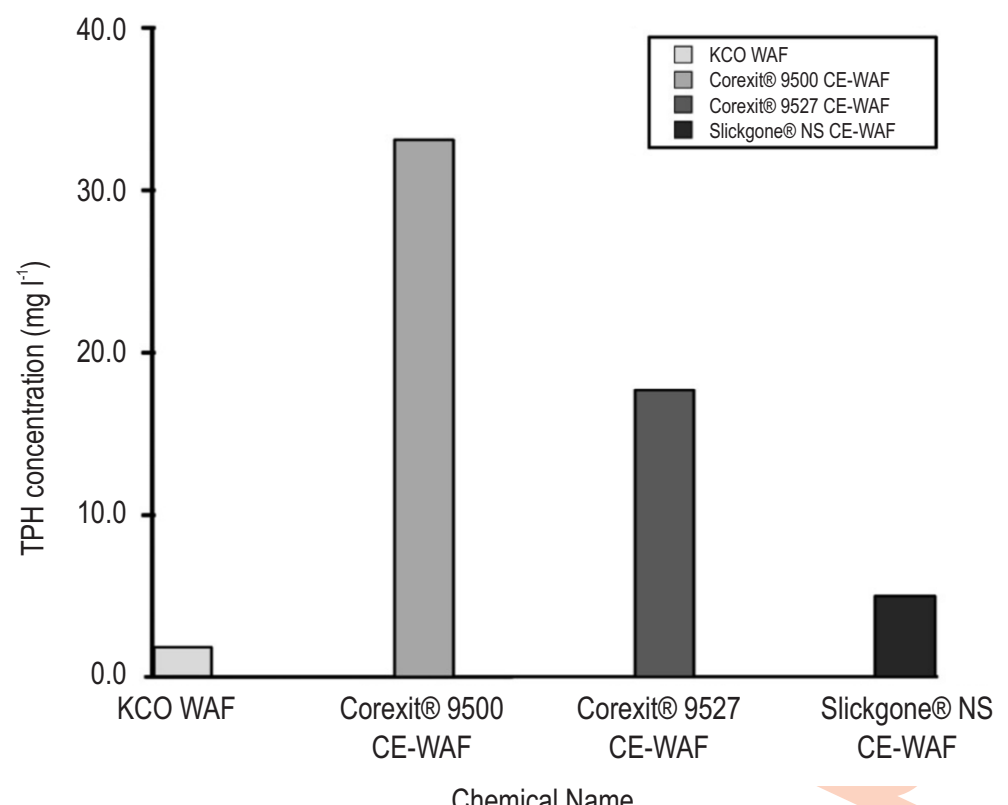

Fig. 1: Total Petroleum Hydrocarbons for KCO WAF (Kuwait Crude Oil Water-Accommodated Fraction) and CE-WAF (Chemically-Enhanced WaterAccommodated Fraction) of Kuwait crude oil with different dispersants (Corexit@ EC 9500A, Corexit@EC 9527A and Slickgone® NS).

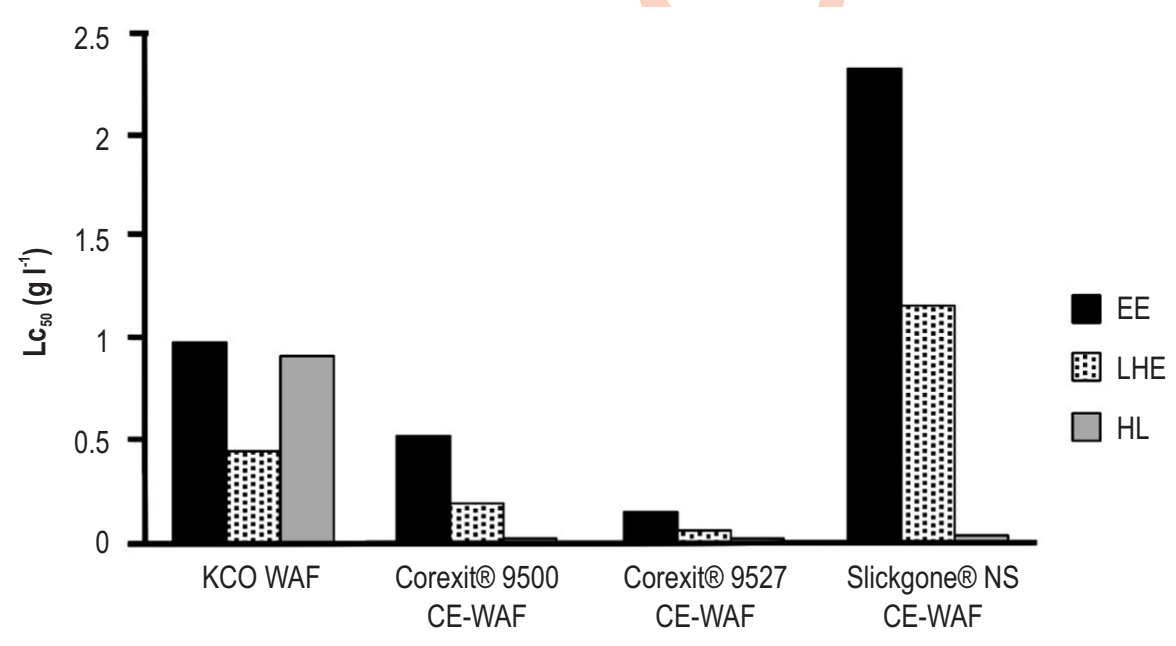

Chemical Name

Fig. 2: Effect of total petroleum hydrocarbon (TPH) concentrations $\left(\mathrm{mg} \mathrm{l}^{-1}\right)$ for KCO WAF (Kuwait Crude Oil Water-Accommodated Fraction) and CEWAF (Chemically-Enhanced Water-Accommodated Fraction) of Kuwait crude oil with different dispersants (Corexit EC 9500A, Corexit ${ }^{\circledR} \mathrm{EC} 9527 \mathrm{~A}$, and Slickgone ${ }^{\oplus} \mathrm{N}$ on embryonated eggs $(\mathrm{EE})$, larvae hatched during exposure $(\mathrm{LHE})$, and post hatched larvae $(\mathrm{HL})$ with $\mathrm{LC}_{50}$ at each exposure.

EE was $0.171 \mathrm{gl}^{-1}$, for LHE the $96 \mathrm{hr} \mathrm{LC}_{50}$ was $0.087 \mathrm{gl}^{-1}$, and for $\mathrm{HL}$ the $96 \mathrm{hr} \mathrm{LC}_{50}$ was $0.010 \mathrm{gl}^{-1}$. Finally for Slickgone® NS CE-WAF, the $48 \mathrm{hr} \mathrm{LC}$ for EE was $2.34 \mathrm{~g} \mathrm{I}^{-1}$, for LHE the $96 \mathrm{hr} \mathrm{LC}$. was $1.185 \mathrm{gl}^{-1}$, and for $\mathrm{HL}$ the $96 \mathrm{hr} \mathrm{LC}_{50}$ was $0.0452 \mathrm{~g} \mathrm{I}^{-1}$ respectively. The toxicity pattern observed for the $E E$ life stage of $E$. coioides showed that Corexit@ 9527 CE-WAF was the most toxic test chemical examined and dispersing KCO with Slickgone® NS was not more toxic than KCO WAF alone. The findings of cohen and Nugegoda (2001) indicate that exposure of fish to Bass Straight crude oil treated with Corexit $₫ 9527$ dispersant resulted in more toxic medium than oil WAF alone without 
adding dispersant to it which is similar to the present findings in case of Corexit $₫$ CE-WAFs. Clark et al. (2001), on the other hand, observed that KCO dispersed with Corexit@ 9527 was more toxic to turbot (Scophthalmus maximus) and inland silverside (Menidia beryllina) embryos and larvae as compared to the present study.

The resistance of fish eggs to oil toxicity was probably due to the presence of egg envelope (chorion) caused by the presence of enzyme transglutaminase (Tgase). Coupled with the vitelline membrane, the chorion protects the developing embryo from external chemical, physical and biological stressors in the marine environment, and also provide some defense mechanism against xenobiotic chemical intoxication (Yamagami et al., 1994 Ha and Luchi, 1998; Finn, 2007). Exposure of LHE stage to KCO WAF and CE-WAFs produced a similar toxicity pattern to what was observed for EE stage.

Successful hatching of fish eggs during exposure to KCO WAF and CE-WAF indicated the resistance of EE towards toxicity. Although, the LHE stage lacked the protection of chorion egg membrane and, at hatching, they became more susceptible to KCO WAF and CE-WAF toxicity, the toxicity pattern was similar to that of EE stage. Previous studies have reported that during early development, damage to few precursor cells resulted in damage to the exposed fish (Greene et al., 2007). The mechanism by which dispersants alter the hydrocarbon bioaccumulation process is not well understood (Mielbrecht et al., 2005).

In this study, KCO CE-WAF caused a sharp decrease in $24 \mathrm{hr} \mathrm{LC}_{50}$ values compared to KCO WAF, indicating quick enhancement of toxicity of KCO by treatment with dispersants. At $48 \mathrm{hr}$, the $\mathrm{LC}_{50}$ values of WAF and CE-WAF were comparable, and with time the severity of toxicity increased with both WAF and CEWAF. The toxicity pattern observed for $\mathrm{HL}$ showed that Corexit $\AA$ 9527 CE-WAF was the most toxic chemical, and KCO WAF was least toxic and Corexit@ 9527 CE-WAF toxicity value was close to that of Corexit $₫ 9500$ CE-WAF. Singer et al. (2000) demonstrated that the primary function of oil spill dispersant was to increase the entry of oil into water column, thereby modifying the exposure medium and increasing its toxicity.

Dispersion of crude oil with oil dispersant (CE-WAF) increased its toxicity in comparison to that of KCO WAF, as dispersants solubilized more of the oil fraction in the water column which rendered it bioavailable to fish larvae (Singer et al., 1998). Jung et al. (2009) reported that addition of dispersants to crude oil enhance the concentration of hydrocarbons available to ovoviviparous rockfish (Sebastes schlegeli), since cytochrome P450-1A and EROD activity increased in the fish after exposure to crude oil WAF after dispersion with the dispersant Corexit@ 9500. (Farid et al., 2016) The results of this study corroborates the findings who reported that dissolved crude oil exerted more effects on hatched larvae than on embryos, and dispersed oil was more toxic to fish larvae than floating oil. The change in the order of toxicity of CE-WAF mixtures may be related to different degradation rates and degradation products of the dispersant, indicating that toxicity data vary for different oil dispersants and crude oil (Pollino and Holdaway, 2002).

In conclusion, the results of the study revealed that the total petroleum hydrocarbons concentrations were higher in dispersed than undispersed oil solutions, which shows that the accommodation of more petroleum hydrocarbons in the aqueous state.

\section{Acknowledgments}

We would like to thank the Kuwait Institute for Scientific Research and Newcastle University for providing facilities carry out this research under the joint exchange program. We would also like to thank Mr. Ali TaherAl-Shobbar for editing the figures.

\section{References}

ADEC: (Alaska Department of Environmental Conservation): Part 2. Assessment for Alaskan marine species for toxicity tests. Report of the Institute of Northern Engineering, University of AlaskaFairbanks. Authored by R.A. Perkins. Alaska Department of Environmental Conservation, Report of the Institute of Northern Engineering, University of Alaska-Fairbanks. (2000).

Abdurahiman, K.P., P.U. Zacharia, T.H. Nayak and K.S. Mohamed: Diet and trophic ecology of silver pomfret, Pampus argenteus (Euphrasen, 1788) exploited from the Southeast Arabian Sea. J. Mar.Biol.Ass., 48, 206-212 (2006).

Abdurahiman, K.P., T.H. Nayak, P.U. Zacharia and K.S. Mohamed: Trophic organisation and predator-prey interactions among commercially exploited demersal finfishes in the coastal waters of the southeastern Arabian Sea. Estuar. Coast. Shelf Sci., 87, 601$610(2010)$.

Afolabi, O.N., S.A. Adeyemi and A.M.A. Imevbore: Studies of the toxicity of some Nigerian crude oils to some aquatic organisms. In: Proceedings of the International Seminar on the Petroleum Industry and the Nigerian Environment, pp. 269-273 (1985).

Baier, C.T. and J.E. Purcell: Trophic interactions of chaetognaths, larval fish, and zooplankton in the South Atlantic Bight. Mar. Ecol. Prog. Ser., 146, 43-53 (1997).

Barron, M.G., M.G. Carls, R. Heintz and S.D. Rice: Evaluation of fish early life-stage toxicity models of chronic embryonic exposures to complex polycyclic aromatic hydrocarbon mixtures. Toxicol. Sci., 78, 60-67 (2004)

Bejarano, A.C., G.T. Chandler, L. He and B.C. Coull: Individual to population level effects of South Louisiana crude oil water accommodated fraction (WAF) on a marine meiobenthic copepod. J. Exp. Mar. Biol. Ecol., 332, 49-59 (2006).

Birtwell, O.K., R. Fink, D. Brand, R. Alexander and C.D. McAllister: Survival of pink salmon (Oncorhynchus gorbuscha) fry to adulthood following a 10-day exposure to the aromatic hydrocarbon water-soluble fraction of crude oil and release to the Pacific Ocean. Can. J. Fish Aquat. Sci., 56, 2087-2098 (1999).

Bonsdorff, E., T. Bakkeand and A. Pedersen: Colonization of amphipods and polychaete to sediments experimentally exposed to oil hydrocarbons, Mar. Pollut. Bull. 21,355-358 (1990).

Brannon, E.L., K.M. Collins, J.S. Brown, J.M. Neff, K.R. Parker and W. A. Stubblefield: Toxicity of weathered Exxon Valdez crude oil to pink 
salmon embryos. Environ. Toxicol. Chem., 25, 962-72 (2006).

Carls, M.G., S.D. Rice and J. E. Hose: Sensitivity of fish embryos to weathered crude oil: I. Low level exposure during incubation causes malformations, genetic damage, and mortality in larval Pacific herring (Clupea pallasi). Environ. Toxicol. Chem., 18, 481 493 (1999).

Cohen, A.M. and D. Nugegoda: Toxicity of three oil spill remediation techniques to the Australian bass Macquaria novemaculeata. Ecotoxicol. Environ. Saf., 47, 178-185. (2001).

Canevari, G.P.: Some Observations on the mechanism and chemistry aspects of chemical dispersion. In: Chemicals dispersants for the control of oil spills. (Eds.: L.T.J. Mccarthy, G.P. Lindblom and H.F. Walter), pp. 2-5(1978).

Clark, J.R., G.E. Bragin, R.J. Febboand and D.J. Letinski: Toxicity of physically and chemically dispersed oils under continuous and environmentally realistic exposure conditions: Applicability to dispersant use decisions in spill response planning. In: Proceedings of the 2001 International Oil Spill Conference, Tampa, Florida. American Petroleum Institute, Washington, D.C. pp. 1249-1255 (2001).

Couillard, C.M., K. Lee, K. Legareand and T.L. King: Effect of dispersant on the composition of the water accommodation fraction of crude and its toxicity to larval marine fish. Environ. Toxicol. Chem., 24, 1496-1504 (2005).

Dasic International Limited: Winchester Hill, Romsey, Hampshire. SO51 7YD, United Kingdom (2007).

Daling, P.S., P.J. Brandvik, D. Mackay and O. Johansen Characterization of crude oils for environmental purposes. In: Proceedings of Thirteen Arctic and Marine Oil Spill Program Technical Seminar. Environment Canada: Biological Test Method: Acute Lethality test Using Three Spine Stickleback (Gasterosteus aculeatus). Environmental Protection Series (1990).

Farid, W. A., A.N. Al-Salman, D.S. Hammad, H.T. Al-Saad, S.M. Salih and A.Z. Al Hello: Toxic effects of dissolved and dispersed crude oils on eggs and larvae of some fishes from ShattAl-Arab River. J. Pharm. Chem. Biol. Sci., 4, 88-103 (2016).

Finn, R. N.: The physiology and toxicology of salmonid eggs and larvae in relation to water quality criteria. Aquat. Toxicol., 81, 337-354 (2007).

Gagnon, M.M. and D.A. Holdway: EROD induction and biliary metabolite excretion following exposure to the water accommodated fraction of crude oil and to chemically dispersed crude oil. Arch. Environ. Contam. Toxicol., 38, 70-77 (2000).

Georgiades, E.T., D.A. Holdway, S.E. Brennan, J.S. Butty and A. Temara: The impact of oil-derived products on the behavior and biochemistry of the eleven armed asteroid Coscinasterias muricata (Echinodermata). Mar. Environ. Res., 55, 257-276. (2003).

Greene, H.G., V.M. O'Connell, W.W. Wakefield and C.K. Brylinsky: The offshore Edgecumbe Lava Field, SoutheastAlaska: Geological and habitat characterization of a commercial fishing ground. Special Paper-GeologicalAssociation of Canada, 47, 277-295 (2007).

Ha, C.R. and I. Luchi: Enzyme responsible for egg envelope (chorion) hardening in fish: Purification and partial characterization of two transglutaminases associated with their substrate, unfertilized egg chorion, of the rainbow trout, Oncorhynchus mykiss. J. Biochem., 124, 917-926 (1998).

Hussain, N., S. Akatsu and C. El-Zahi: Spawning, egg and early larval development, and growth of Acanthopagrus cuviere (Sparidae). Aquaculture, 22, 125-136 (1981).

Jung, J.H.: Biochemical changes in rockfish, Sebastes schlegeli, exposed to dispersed crude oil. Comp. Biochem. Physiol. C. Pharmacol., 150, 218-223 (2009).

Karam, Q., M.U. Beg, A. Al-Khabbaz, Z. Al-Ballam, S. Dakour and K. Al-
Abdul Elah: Effect of water-accommodated fraction of Kuwait crude oil on developmental stages of orange-spotted grouper hamoor (Epinephelus coicoides). Int. J. Adv. Agri. Environ. Eng., 1, 105-112 (2014).

Kemadjou, J.: Effects of crude oil on zebrafish embryos. Eawag News, 64, 24-26 (2008).

Kuhnold, W.W.: The influence of crude oil on fish fry. Marine Pollution and Sea Life. FAO Fishing News Ltd., London, pp. 315-318 (1970).

Martínez-Gómez, C., A.D. Vethaak, K. Hylland, T. Burgeot, A. Köhler, B.P. Lyons, J. Thain, M.J. Gubbins and I.M.A. Davies: Guide to toxicity assessment and monitoring effects at lower levels of biological organization following marine oil spills in European waters. J. Mar. Sci., 67, 1105-1118 (2010).

Mielbrecht, E. E., M.F. Wolfe, R.S. Tjeerdemaand and M. L. Sowby: Influence of dispersant on the bioaccumulation of phenanthrene by topsmelt Atherinops affinis. Ecotoxicol. Environ. Saf., 61, 44-52 (2005).

Minitab version 17 Statistical Software. [Computer software]. State College, PA: Minitab, Inc. (www.minitab.com). (2016).

Moles, A.S., D. Rice and S. Korn: Sensitivity of Alaskan freshwater and anadromus fishes to Prudhoe Bay crude oil and benzene. Tran. Am. Fish. Soc., 108, 408-814 (1979).

MOOPAM (Manual of Oceanographic Observation and Pollution Analysis Methods). Regional Organization for the Protection of the Marine Environment. $3^{\text {rd }}$ Edn., Kuwait (1999).

Norcross, B.L., F. Muter and B.A: Holladay: models for juvenile pleuronectids around Kodiak Island, Alaska. Fish. Bull., 95, 504520 (1997).

NRC (National Research Council): Oil in the Sea, Inputs, Fates and Effects. National Academy Press, Washington, D.C. (1985).

NRC (National Research Council): Oil in the Sea: Inputs, Fates, and Effects. National Academy Press, Washington, D.C. (2003).

Nyman, J. A., P.L. Klerk and S. Bhattacharya: Effect of chemical additives on hydrocarbon disappearance and biodegradation in fresh water marsh microcosms. Environ. Pollut., 149, 227-238 (2007).

OCED (Organization for Economic Co-Operation and Development): OCED Guideline for The Testing of Chemicals. Draft Proposal for a New Guideline, Fish Embryo Toxicity (FET) Test (2006).

Otitoloju, A.A. and O. A. Adeoye: Taintging and weight changes in Tilapia guineensis exposed to sublethal doses of crude oil. Bioscience Res. Comm., 15, 91-99 (2003).

Otitoloju, A.A.: Crude oil plus dispersant: Always a boon or bane? Ecotoxicol. Environ. Saf., 60, 198-202 (2005).

Pearce, F.: What turns an oil spill into a disaster? New Scientist, 137, 1113(1993).

Pollino, C. A. and D. A. Holdway: Toxicity testing of crude oil and related compounds using early life-stages of the crimson-spotted rainbow fish Melanotaenia fluviatilis. Ecotoxicol. Environ. Saf., 52, 180-189 (2002).

Pollino, C.A. and D.A. Holdway: Hydrocarbon-induced changes to metabolic and detoxification enzymes of the Australian crimsonspotted rainbow fish Melanotaenia fluvialilis. Environ Toxicol., 18, 21-28 (2003).

Powell, C. B., B. Baranowski-Dutiewics, M. Isoun, D.D. Ibiebele, F.U. Ofeogbi and S.A. Whyte: Oshika oil spill environmental impact: Effect on aquatic environment. In: Proceedings of International Seminar on Petroleum Industry and the Nigerian Environment., pp. 181-201 (1985).

Raimondo, S., C.R. Jackson, J. Krzykwa, B.L. Hemmer, J.A. Ackerman and M.G. Barron: Developmental toxicity of Louisiana crude oilspiked sediment to zebrafish. Ecotox. Environ. Safety., 108, 265272 (2014). 
Ramachandran, S.D., P.V. Hodson, C.W. Khan and K. Lee: Oil dispersant increases PAH uptake by fish exposed to crude oil. Ecotoxicol. Environ. Safety., 59, 300-308 (2004).

Randall, J.E.: Coastal fishes of Oman. University of Hawaii Press, Honolulu, Hawaii (1995).

ROPME (Regional Organization for the Protection of Marine Environment): Use of Oil Spill Chemicals in the ROPME Sea Area. ROPME/GC-9/004, Kuwait(1998).

Samuel, O.B., O.Q. Suleiman and W.O. Odiete: Synergistic evaluation of oil-dispersant and oil-detergent mixtures using African catfish, Clarias gariepinus fry. J. Fish. Aquat. Sci., 3, 280-290 (2008).

Sadovy de Mitcheson, Y., M. T. Craig, A. A. Bertoncini, K. E. Carpenter, W. W.L. Cheung, J. H. Choat, A. S. Cornish, S. T. Fennessy, B. P. Ferreira, P.C. Heemstra, M. L. Robert, F. Myers, D. A. Pollard, K. L. Rhodes, L.A. Rocha, B.C. Russell, M.A. Samoilys and J. Sanciangco: Fishing groupers towards extinction: A global assessment of threats and extinction risks in a billion dollar fishery. Fish Fish., 14, 119-136 (2013).

Shales, S.: Biological and ecological effects of oils. In: The Fate and Effects of Oil in Freshwater (Eds.: J. Green and M. Truett). British Petroleum Co. and ElsevierApplied Science, London, New York, pp. 81-106 (1989).

Singer, M. M., D. Aurand, G.E. Bragin, J.R. Clark, G.M. Coelho, M.L Sowby and R.S. Tjeerdema: Standardization of the preparation and quantification of water-accommodated fractions of petroleum for toxicity testing. Mar. Pollut. Bull., 40, 1007-1016 (2000).

Singer, M.M., S. George, I. Lee, S. Jacobson, L.L. Weetman, G. Blondina, R.S. Tjeerdema, D. Aurand and M.L. Sowby: Effects of dispersant treatment on the acute aquatic toxicity of petroleum hydrocarbons. Arch. Environ. Contam. Toxicol., 34, 177-187 (1998).
Slickgone, N.S: Material Safety and Data Sheet. Dasic International Ltd. UK. (2007).

Sluka, R.D., M. Chiappone and K.M. Sullivan Sealey: Influence of habitat on grouper abundance in the Florida Keys, U.S.A.J. Fish Biol., 58, $682-700$ (2001)

SOAFD (Scottish Office Agriculture and Fisheries Department) In: Interim Report of the Marine Monitoring Programme on the Brauer Oil-Spill, Marine Laboratory, Aberdeen (1993).

Struhasker, J.W., M.B. Alderdice and T. Echeverria: Effects of benzene (a water-soluble component of crude oil) on eggs and larvae of Pacific herring and northern anchovy. In: Pollution and Physiology of Marine Organisms (Eds.: F.J. Vernberg and W.B. Vernberg). Academic Press, New York, pp. 253-284 (1974).

UNEP (United Nations Environment Program): Overview on Land-based Sources and Activities Affecting the Marine Environment in the ROPME Sea Area. UNEP Regional Sea Reports and Studies No. 168 (1999).

Venosa, A.D. and E. L. Holder: Biodegradability of dispersed crude oil at two different temperatures. Mar. Pollut. Bull., 54, 545-553 (2007).

Wheelock, C. E., T.A. Baumgartner, J.W. Newman, M.F. Wolfe and R.S. Tjeerdema: Effect of nutritional state on Hsp60 levels in the rotifer Brachionus plicatilis following toxicant exposure. Aqua. Toxicol., 61, 89-93 (2002).

Wolf, G.A., M.R. Preston, G. Harriman and S.J. Rowland: Some preliminary observations after the wreck of the oil tanker Braer in Shetland. Mar. Pollut. Bull., 26, 567-571 (1993).

Yamagami, K., K. Murata, T.S. Hamazaki and I. luchi: Intrahepatic formation of SF substances, the precursors of egg envelope proteins, in response to estrogen administrationin fish. In: Perspective in Comparative Endocrinology (Eds.: K.G. Davey, R.E. Peter and S.S. Tobe). National Research Council of Canada, pp. 316-324 (1994).

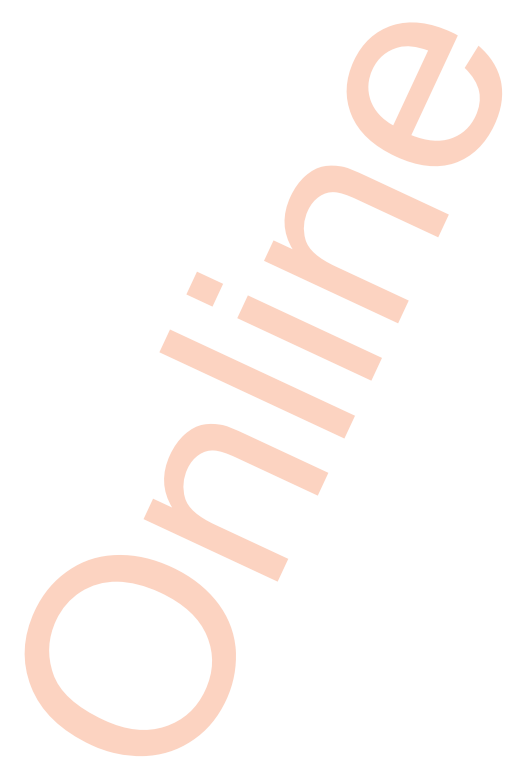

